HAVRANCSIK DÁNIEL

\title{
A RÉTEGZETT MODERNITÁS INTEGRÁCIÓELMÉLETE
}

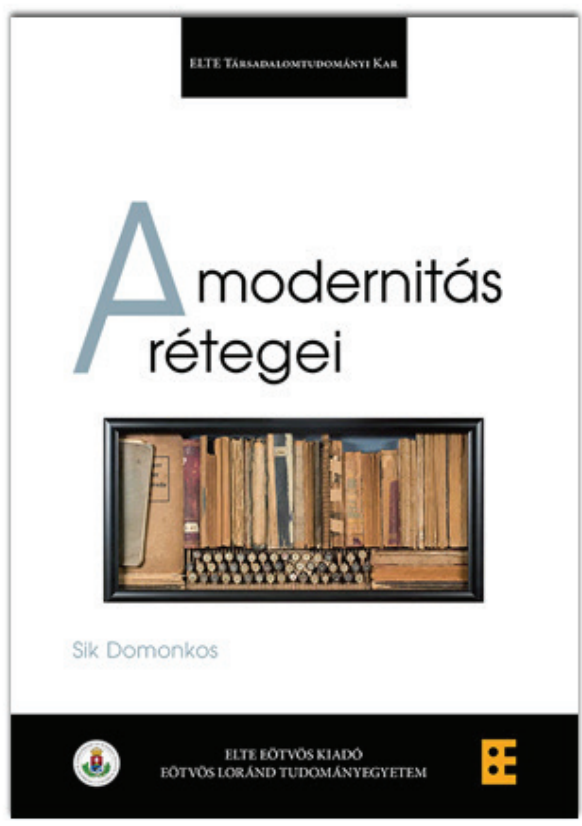

Sik Domonkos (2015) A modernitás rétegei

Budapest: ELTE Eötvös

DOI: 10.18030/SOCIO.HU.2016.3.111

Sik Domonkos nagyszabású vállalkozása, mely egy a magyarországi viszonyokat szem előtt tartó, a legszigorúbb elméleti igényeknek is megfelelően megformált átfogó kritikai társadalomelmélet kialakítására irányul, a legutóbbi tanulmányainak ${ }^{1}$ eredményeit összegző, A modernitás rétegei címú kötettel új állomáshoz érkezett. Miután legutóbbi, Demokratikus kultúra és modernizáció (Sik 2014a) címú, második könyvében az állampolgári szocializáció magyarországi körülményeinek empirikus vizsgálatával próbált fényt deríteni a modernizáció stabilitásának feltételeire, ezúttal az első könyvben felvázolt elméleti keret továbbépítésére, perspektívájának tágítására tett kísérletet.

Sik a társadalmi integráció általános elméletének normatív megalapozását célul kitűző, $A$ modernizáció ingája (2012) címú könyvében azt próbálta meg elméleti eszközökkel megragadni, hogy miként alakul ki az autonómia a demokratikus állampolgári kultúra elsajátítása során egy ezt nem valószínűsítő közegben. A szerzőt foglalkoztató kérdés - miként biztosíthatóak azok a demokratikus értékek, amelyek egy modern társadalom kiegyensúlyozott múködésének alapjául szolgálhatnak - változatlan, A modernitás rétegeiben azonban a probléma más perspektívából kerül áttekintésre. A különbségek röviden három pontban foglalhatók össze: először, „míg az első könyv az állampolgári kultúra és az autonómia kialakulásának mechanizmusát rekonstruálta, és ebböl lépett tovább a társadalmi integráció és a modernitás problémái felé, addig jelen írás közvetlenül az integráció és a modernitás kérdéseivel foglalkozik, és innen lép vissza a cselekvőperspektiva és az interakciók fenomenológiai jellemzéséhez." ${ }^{2}$ A második eltérés az, hogy míg az első könyvben a cselekvéskoordinációs me-

1 Anthony Giddens és Scott Lash munkásságát bemutató írásai mellett lásd elsősorban Sik 2014b, 2015.

2 A modernitás rétegei, 213. A továbbiakban a külön megjelölés nélküli oldalszámok erre a kötetre vonatkoznak. 
chanizmusok egy hálózatelméleti keretben kerültek bemutatásra, addig $A$ modernitás rétegeiben közvetlenül az integrációs mechanizmusok egymáshoz való viszonya a vizsgálat tárgya. Végül a harmadik, bizonyos értelemben a könyv legfőbb újítását jelentő különbség, hogy a kiindulópontok közé a szerző ezúttal beemelte a késő modernitás elméleteit, hogy a modernizáció tendenciájában jelentkező olyan újabb fejleményekre, mint például a globalizációra, az információtechnológiai robbanásra vagy az új kockázatok és kontingenciák megjelenésére irányuló reflexiók bevonásával árnyalja kordiagnosztikai képét.

A könyvben felvázolt átfogó elmélet ezúttal is ismert teoretikusok megközelítéseinek gondos szintetizálásával került kialakításra, akiknek névsora a megváltozott perspektívának megfelelően csak részben van fedésben az előző elméleti munkában találhatóval. A modernizáció ingájában fontos szerepet betöltő Jürgen Habermas és Pierre Bourdieu ezúttal mint a klasszikus modernitás elméletalkotói jutnak szóhoz; hozzájuk újonnan érkezőként Anthony Giddens és Scott Lash, mint a modernitás újabb hullámának teoretikusai csatlakoznak.

Az első könyv központi motívumát, a modernizáció - emancipatorikus és patologikus tendenciák közti ingamozgását a rétegek metaforája váltja fel, a modernizáció különböző szakaszainak megfelelő integrációs mechanizmusok egymásra halmozódására utalva. Egy modern társadalom integrációs mechanizmusainak adott rendszere a modernizáció különböző szakaszaiban jelentkező integrációs logikák egymás mellé rendelődéseként értelmezhető; az újabb integrációs formák térnyerésével a régebbiek hatóköre módosul ugyan, de érvényességüket nem vesztik el. Egy adott társadalom integrációs viszonyaiban rejlő emancipatorikus potenciálok és patologikus tendenciák pillanatnyi konstellációja a különböző korszakokból származó, egymást részben átfedő integrációs logikák egymásra rétegződéséből rajzolódik ki.

Sik Domonkos a négy elméletalkotó, a modernizáció különböző szakaszaira és dimenzióira vonatkozó meglátásait összegezve jut el a rétegzett modernitás átfogó integrációelméletéhez, mely végül alkalmas elméleti keretnek bizonyul ahhoz, hogy a rendszerváltás utáni Magyarország társadalmi berendezkedésének viszszásságait és esélyeit megvilágító, empirikus kutatások eredményeinek széles körére támaszkodó kordiagnózis alapjául szolgáljon. A társadalmi integráció strukturális sajátosságait a szocializmusnak a klasszikus modernitás horizontján mozgó integrációs logikája és a második vagy reflexív modernitás integrációs logikája ütközéseként megragadó nézőpont árnyaltabb képet fest a jelenkori Magyarország viszonyairól, mint azok a megközelítések, amelyek a „megkésett” vagy „felemás” modernizáció téziséből kiindulva, a modernizáció egydimenziós elképzelésére támaszkodva képtelennek mutatkoztak a késő modernitás sajátos tendenciáinak a rendszerváltást követően Magyarországra is begyűrűző hatásait regisztrálni.

A rendkívül lényegre törően megírt bevezetőt a könyv első nagyobb - a könyv közel felét kitevő - tartalmi egységeként Giddens és Lash munkásságának ismertetése követi. Elméleteik igen részletes bemutatását az eddigi magyar nyelvű recepció hiányossága indokolja; a Sik által már az eddigiekben is nagy haszonnal tanulmányozott Habermas és Bourdieu elméleteinek taglalására - Magyarországon jól ismert szerzők révén - nem kerül sor. Giddens és Lash elméleteinek bemutatásánál Sik jócskán meghaladja az ismertetésnek azt a mértékét, amelyet önálló argumentációja önmagában feltétlenül megkívánna, így e két fejezetet haszonnal forgathatja az az olvasó is, aki kizárólag Giddens vagy Lash elmélete iránt érdeklődik; e fejezetekben Sik pusztán mint tolmács nyilvánul meg. 
Bár Anthony Giddens korunk egyik legismertebb szociológiai teoretikusa, Magyarországon mindmáig elsősorban tankönyvszerzőként ismert. Az önálló társadalomelméletére vonatkozó recepció ${ }^{3}$ hiányosságát pótolandó, Sik Domonkos igen részletesen tárgyalja az angol szerző életmúvét, felhívva ugyanakkor a figyelmet arra, hogy a tágabb elmélettörténeti kontextus taglalásának hiányában elemzése nem tekinthető teljesnek. Giddens személyében olyan szerzőről van szó, aki remekül illeszkedik a Sik által kialakított sémába: tematikusan rendkívül kiterjedt elmélete, melyben egymást feltételező, egymásra épülő egységekként kapcsolódnak össze a társadalomtudományos episztemológiai, kordiagnosztikai és a politikai praxisra vonatkozó megfontolások, a klasszikus modernitás értékei mellett kiállva próbál magyarázatot adni a késő modernitás jelenségére, miközben aktív dialógust folytat a klasszikus szociológiai elméleti hagyományokkal is.

Giddens társadalomelméletének központi fogalma a strukturáció, vagyis a cselekvések kereteként szolgáló intézményi struktúrák cselekvések révén történő újratermelődése. Szakítva a megszokott struktúrafogalom által sugallt determinisztikus emberképpel, Giddens olyan cselekvőkkel számol, akik nincsenek teljes mértékben alávetve a strukturális kényszereknek; a struktúrák újratermelődése részben éppen az autonóm lényekként eljáró, önmagukat folyamatosan monitorozó cselekvők döntései nyomán valósul meg. A környezetére folyamatosan reflektáló, annak befolyásolására képes cselekvő és a cselekvők felől jövő impulzusok iránt nagymértékben nyitott intézményi struktúrák dinamikus viszonya nem a determináció, hanem a reflexivitás fogalmaiban ragadható meg.

Köszönhetően annak, hogy sem a struktúra, sem a cselekvő analitikus szintjét nem tünteti ki elsőbbséggel, a strukturációelmélet számára egy különösen széles látószög tárul fel. Csak egy ilyen, a cselekvések tudatosuló, nem tudatosuló és tudatalatti formáinak, valamint az intézményi struktúra szemantikai, hatalmi és normatív dimenzióinak együttes áttekintésére alkalmas elmélet lehet képes a modernitást a maga teljes komplexitásában tematizálni - állapítja meg Sik. Ebben az elméleti keretben a modernitás dinamikáit érintő változások a stukturációs dimenziók (politikai, gazdasági, jogi intézmények, diszkurzív rendek) közti viszonyok átrendeződéseként ragadhatók meg.

Giddens modernizációelméletének kiindulópontjául az a belátás szolgál, hogy a modernitást együttesen hordozó intézményrendszerek - a kapitalista árutermelés, a természet technikai-ipari igénybevétele, az információ és a gyakorlatok feletti állami kontroll, valamint az államon belüli és államközi erőszak kontrollja - stabilitására való tekintettel téves posztmodern korról, a modernitás kontinuitásának megtöréséről beszélni, szerveződésüknek a nemzetállami kereteken való túlnyúlása és az ezzel összefüggő szociokulturális változások ugyanakkor indokolttá teszik, hogy a késő modernitás időszakát megkülönböztessük a klasszikus modernitásétól.

Az új szakaszába lépő modernitás megkülönböztető jegye az élet legkülönbözőbb területein jelentkező, a tradicionális tehermentesítő mechanizmusok által nem semlegesített kontingenciák felszaporodása, mely a figyelmet a potenciális kockázatokra irányítva mind cselekvői, mind intézményi szinten kikényszeríti a reflexivitás fokozódását. A megkérdőjelezhetetlen tekintélyek és a stabil hierarchikus viszonyok által képviselt egydimenziós világértelmezési sémák és a rájuk épülő intézményi struktúrák iránti bizalom megrendül; a monolit világ-

3 Mindenképpen említést érdemel ugyanakkor a Replika 82., Berger Viktor és Sik Domonkos által szerkesztett Giddens-szel foglalkozó száma. 
értelmezés bizonyossága átadja helyét a lokalitástól eloldódott virtuális rendszerek és az eltérő szempontokat képviselő szakértői testületek által közvetített plurális világértelmezés bizonytalanságának. A klasszikus modern kor értelmi viszonyai mintegy automatikusan biztosítottak az egyes személy számára egy többé-kevésbé stabil identitást, és szavatolták a világban való otthonosság minimumát, vagyis - Giddens szavaival - megteremtették ontológiai biztonságát. A tradicionális értelmezési sémák érvényvesztésével megrendülnek az ontológiai biztonság alapjai is; ekkor az egyes individuumra hárul annak feladata, hogy az életkörülményeit övező bizonytalanságokban a szabadság és az autonómia lehetőségeit meglátva életútjának tudatos vezetésével önállóan biztosítsa egzisztenciális állásait. Ahhoz, hogy úrrá legyen saját kiszolgáltatottságán, fel kell készülnie arra, hogy az élet minden területén önálló döntéseket kell hoznia; ahhoz, hogy felelős döntéseket hozhasson, a kockázatok folyamatos mérlegelésében megnyilvánuló önreflexióra van szüksége. A késő modernitásra voltaképpen nem a kontingenciák tényleges mértékének megszaporodása jellemző, hanem az, hogy leépült azok intézményi koordinációja, így a cselekvők kénytelenek reflexív viszonyt kialakítani a kontingenciákkal.

A késő modernitás változásai azonban nem csak veszélyeket, hanem sajátos új esélyeket is tartogatnak. Az autonóm identitás-formálás lehetősége és az új típusú intim viszonyok mellett sajátos új emancipatorikus potenciált hordoznak a politikai aktivitás terén megnyíló új horizontok is. A fejezetet a késő modernitás kibontakozásának politikai következményeivel kapcsolatos giddens-i várakozások ismertetése zárja.

A hazánkban mindeddig kevéssé ismert (bár lásd Sik 2013) Scott Lash pályája egy szokványosnak mondható szociológiai megközelítéstől egy a szűken értelmezett szociológia érdeklődési területeinek határain túlnyúló átfogó modernitáselmélet kidolgozásáig ível. Eleinte gyakori szerzőtársával, John Urry-vel írt könyveiben marxi kiindulópontokról vizsgálta a hatást, amelyet a kapitalizmus megszokott szervezeteinek lebomlása gyakorol a munkásosztály politikai aktivizmusára; majd a szervezett kapitalizmus hanyatlásával párhuzamos, ám annál nagyobb hatókörű modernizációs tendenciák megragadását kísérelte meg egy, a társadalmi meghatározottságok viszonyai felől az individuális szubjektumot érintő átalakulások felé forduló, egyre inkább posztmodern elméletek által inspirált megközelítésben; munkásságát végül egy, a „másik modernitásra” szabott kritikai elméletben tetőzte be.

Lash szerint a másik modernitás kibontakozásával a klasszikus modernitást fenntartó intézményi struktúrák jelentősége csökken, és helyüket globális „áramlások” veszik át; a tőke, a termelés, a fogyasztás és az információterjedés viszonyainak átalakulása egyaránt az áramlás fogalmával ragadható meg. Ezzel párhuzamosan az egyenlőtlenségi viszonyokat meghatározó tényezők terén is hangsúlyeltolódás történik: az információhoz való hozzáférés válik a leginkább meghatározó rétegképző elvvé. Giddens-hez - és Ulrich Beckhez - hasonlóan Lash is úgy véli, hogy a globális átalakulásokat az egyes individuum szintjén a reflexió fokozódása kíséri, ám véleménye szerint az új keletű reflexivitás eredendően nem kognitiv, hanem esztétikai természetû. Sik Domonkos tolmácsolásában: „Az esztétikai jelző mindenekelött úgy értendő, hogy a szabadidő növekedésével, a szolgáltatói középosztály megjelenésével, a posztadoleszcencia életúton belüli elkülönülésével létrejött egy olyan cselekvési tér, ahol a tetszés tudományos-morális szempontoktól független, szubjektiv szempontjai alapján születnek döntések." (68) 
A rendszerint a kollektivitások viszonyai és az „azonosság racionalitása” iránt érdeklődő klasszikus szociológiai szemléletmód felől a kultúraelmélet felé fordulva Lash perspektívája a társadalmiság kötelmei alól mindinkább mentesülő individuum szubjektív világtapasztalása felé nyílt meg. Elméleti fogódzóira a klasszikus modernitás osztályozási logikáját visszautasító szemléletmódokban talált rá: a partikularitást rehabilitáló posztmodern építészet, Simmel Nietzsche által inspirált impresszionisztikus szociológiája, és mindenekelőtt a differencia derridai fogalma mutatják az utat a másik modernitás kordiagnózisához.

Lash szerint a másik modernitás társadalma elsősorban az információs társadalom fogalmával ragadható meg - ennek megfelelően a globális információs korban a releváns kritikai társadalomelméletnek is információkritikaként, médiakritikaként kell fellépnie. Az információs társadalomban a világban való tájékozódás bevett formáit elmossa a média által ontott, tömörített és dekontextualizált, koherens egységekké sosem összeálló értelem-fragmentumokból álló áradat, amely puszta differenciává bontja a bevett értelmezési sémákat, és mely önmagát is felemésztve az indifferencia tengerébe torkollik. Az értelemképződés mediatizálttá válásával eltûnnek a cselekvőket eligazító kognitiv fogódzók; a narratív világértelmezési séma felbomlásával az emberi egzisztencia nem kevésbé alapvető meghatározottságai szenvednek el gyökeres változást, mint a tér- vagy az időérzékelés. A szubjektum-objektum dichotómia felolvad; a koherens kulturális miliőben nevelkedett individuumokat - véli Lash Bruno Latourral - emberek és tárgyak hibrid hálózatai váltják fel, az elidegenedés egészen új dimenzióit megnyitva. A narratív értelemképződés ellehetetlenülésével keletkező ürt nem képes betölteni a pontszerú információk halmaza, amelyen sem az identitását kiformálni vágyó individuum, sem az ideológiakritika bevett eszköztárával felfegyverzett kordiagnoszta nem talál fogást. A klasszikus modernitás letűntével, az eddigi eligazodási pontok elérvénytelenedése után sem az egyes egyén, sem a késő modernitás viszonyai iránt érdeklődő kutató nem bízhat másban, mint az értelemképződés újonnan megnyíló szabadságában, a világtapasztalás metaforikus formáiban és a mindent átható esztétikai reflexivitásban.

Giddens és Lash elméleteinek taglalása után Sik rátér önálló integrációelmélete felvázolására. Miután az utóbbi szerzők elméleteinek bemutatása során az olvasót is felvértezte a késő modernitás horizontján felbukkanó újabb tendenciákra vonatkozó ismeretekkel, a reflexív modernitás elméleteit a klasszikus modernitás Habermas és Bourdieu által képviselt leírásával összekapcsolva immár minden elméleti eszköz adott a rétegzett modernitás integrációs sajátosságaiból fakadó patologikus tendenciák és emancipatorikus potenciálok mérlegének megvonásához, vagyis a modernitás „kritikai átvilágításához”. Ezen a ponton a könyvben fordulat történik: a kiinduló elméletek rendkívül módszeres elemzésére, majd elmélettechnikailag roppant átgondolt szintetizálására váltva a szöveg olyan mértékben tömörré válik, amely szociológiaelméleti írásban még a metaelméleti fejtegetések mércéjével mérve is ritkának számít, és melynek lépéseit közelebbről követni egy recenzió keretei közt nem nyílik lehetőség. Ennek megfelelően a továbbiakban csak a főbb eredményekre utalok. ${ }^{4}$

Sik kiváló metaelméleti éleslátásról tanúbizonyságot téve közelíti egymáshoz a négy elméletet: elsőként úgy játssza ki őket egymás ellen, hogy kölcsönösen felfedjék egymás vakfoltjait és gyengeségeit, majd a felhasználható elemeket egy, a négy koncepció erősségeit egybeforrasztó átfogó keretben rendezi el. A szintézist megelőzően a szerző az alapján értékeli az elméleteket, hogy azok milyen választ adnak három, az elmé-

4 A felvázolt metaelméleti szempontrendszer gazdagságát jól szemlélteti az ötödik, $A$ késő modernitás kritikai elméletei címú ábra, mely a könyv 137. oldalán található. 
letépítés szempontjából alapvető kérdésre: milyen értékekre támaszkodva alapozható meg az elmélet? Milyen fogalmi keretekkel ragadhatók meg a társas cselekvéseket koordináló mechanizmusok? És végül: hogyan írhatók le empirikusan a modernitás emancipatorikus és patologikus tendenciái? Az elméletek gondos átvilágítása után a szintézis hasonló lépéseket követve bontakozik ki: Sik először az értékvonatkoztatás szintjén vázol fel egy olyan normatív bázist, amely egységes alapul szolgál az eredményeknek. Ezt követően a társadalmi integráció különböző modelljei közti kölcsönhatást vizsgálja, végül az így nyert átfogó keretben mutat rá a modernitás emancipatorikus és patologikus tendenciáira.

A lépésről lépésre haladó elemzésből végül kibontakozik az az igen komplex modell, amely a feldolgozott elméletek olyan elemeit, mint például a nyelvileg újratermelt életvilág, az információ és az információs hálózatok, az esztétikai, kognitív és intézményi reflexivitás vagy a habitus és a mező, egyfelől az integráció Giddens által javasolt tudatosuló, nem tudatosuló és objektív (vagyis szubjektivitástól független) szintjeihez, másfelől az integráció három analitikusan elkülöníthető, a társadalmi integráció körforgásának három határállapotára utaló eltérő integrációs logikához rendeli, és amely a klasszikus és késő modernitás egyesített kritikai elméletének szemléleti kerete címú ábrában nyer áttekinthető alakot. (156) A három integrációs logika megjelölése a könyv egyik központi eredménye; a konzerváló integrációs logika fogalma a modernitás tradicionalizálódására, valamint a meglévő rutinok és struktúrák fenntartására, a reflexív integrációs logika fogalma a „modernitás szüntelen éberségére", vagyis a tradicionalizálódást ellensúlyozó kritikai öntudatra, a kibernetikai integrációs logika fogalma pedig az intézményi szinten jelentkező rendszerszerú szabályozó mechanizmusok funkcionális teljesítményére, egyszersmind az általa hordozott, a modernitás önfelszámolásával fenyegető gyarmatosító potenciálra utal. Funkcionális értelemben egyik integrációs logikát sem illeti meg elsőbbség; a társas cselekvéskoordináció feladatának ellátásához mindhárom együttes múködésére van szükség. A Sik által felvázolt kritikai elmélet normatív alapja a három integrációs logika egyensúlyában keresendő.

Az integrációs logikák azonosítása után lehetőség nyílik arra, hogy a késő modernitásra vonatkozó kritikai kordiagnózis kialakításának kezdőlépéseként megjelöljük az egyes integrációs logikákon belüli, és az azok közti metaintegrációs viszonyban jelentkező pozitív és patologikus tendenciákat. Vázlatosan: a konzerváló integrációs szféra pozitív integratív hozadéka az ontológiai biztonság biztosítása, jellemző patologikus teljesítménye pedig a strukturális egyenlőtlenségek fenntartása. A reflexív integrációs logika emancipatorikus potenciálja a szüntelen kritikai monitorozás lehetőségében rejlik, a túlzott mértékben elharapózó reflexivitás azonban dezintegrációhoz vezethet. A kibernetikai integrációs logika kiegyensúlyozott integrációs konstelláció esetén fokozott integrációs és adaptív képesség biztosításával járul hozzá az össztársadalmi múködéshez, medréből kilépve azonban eldologiasodáshoz vezet. A metaintegráció szintjén a potenciálisan jelentkező emancipatorikus és patologikus tendenciák az integrációs logikák páronkénti interakcióinak taglalásával kerülnek megvilágításra. A fejezet tanulságait jól áttekinthető formában A rétegzett modernitás tendenciái című, a különböző integrációs logikákra és ezek kapcsolataira jellemző patológiákat, emancipatorikus potenciálokat és modernizációs dinamikákat összegyújtő ábra (156) foglalja össze.

Az általános elméleti keret felvázolása után Sik hozzálát, hogy eredményeit a rendszerváltás utáni Magyarország sajátos viszonyait megvilágító kordiagnózis felállításánál hasznosítsa. A szerző a rendszerváltás óta 
készült empirikus vizsgálatok széles körére támaszkodva igyekszik detektálni a társadalmi integráció különböző szféráiban és azok kölcsönös viszonyában jelentkező patológiákat, és próbálja meg felkutatni azokat az emancipatorikus esélyeket, melyek kiindulópontul szolgálhatnak társadalompolitikai döntések meghozatalánál. Diagnózisa igen borúlátó:

„(...) az elmúlt húsz évben a különböző forrásból származó patológiák egy különösen stabil rendszerré álltak össze. Az államszocializmus évei alatt felhalmozódott problémák, a rendszerváltás politikai és gazdasági kihivásaira adott inadekvát válaszok, valamint a globális információs társadalom kockázatai egymást kölcsönösen felerösitették. Egy olyan állapotot konzerváltak, melyben az egyenlötlenségek, a bizonytalanság, és a dogmatikus világértelmezések dominánssá váltak, beszükitve a reflexió terét és saját képükre formálva az új integrációs logika által meghatározott cselekvési szférákat is. A rétegzett modernitás e konstellációjának leglátványosabb problémáit alighanem az elsődleges patológiák adják, vagy a konzerváló szférát jellemző egyenlötlenség, illúzió és bizonytalanság. Azonban mégsem ezek tekinthetők az emancipáció kulcsának, hanem a metaintegráció szintjén értelmezhető másodlagos és harmadlagos patológiák. Vagyis a konzerváló integrációs logika másik két cselekvési szférát gyarmatositó hatása, valamint a kibernetikai hálózatok - ezzel részben összekapcsolódó - reflexivitást gyarmatosító hatása. Ezek ugyanis magát a patológiák megszüntetésének lehetőségét számolják fel. Minthogy az egyes integrációs szférákhoz kapcsolódó elsődleges patológiák megoldásának kulcsa az alternativ integrációs szférákban rejlik, a döntő tényező a köztük zajló interakció." (202-203)

Az interakció elsősorban a különböző integrációs logikák eltérő mintázatai által koordinált cselekvők interakciójaként képzelhető el: „A metaintegráció patológiája általánosságban a különböző integrációs logikák szerinti cselekvési szférák gyarmatositásaként értelmezhetö. A cselekvéshelyzetek szintjén ez a különböző logikákhoz igazodó cselekvők közti interakció hatalmi torzitására vezethető vissza. Ebben az értelemben a metaintegráció patológiája végső soron interakciós problémaként írható le. Ebből következően emancipációja is az interakciók szintjén azonositható." (207) A rendszerváltás utáni magyar társadalomra egy sajátos perspektivikus fragmentáltság jellemző: a sikeres integráció esélyeit csökkenti, hogy olyan cselekvőket kéne egymáshoz kapcsolnia, akik a különböző integrációs logikák szféráiban való eltérő mintázatú involváltságuk miatt különböző mértékben részesültek az egyes integrációs mechanizmusok kedvező és kedvezőtlen hatásaiból, és ennek megfelelően cselekvői perspektíváik közt jelentős különbség figyelhető meg. A korábbi tapasztalatok és a kilátások különbözősége azonban nem csak a szociális kohéziót gátló tényezőként értékelhető; az eltérő tapasztalati terek eltérő reflexiós horizontokat nyitnak meg, melyek egymáshoz kapcsolásával megnyílnak a társadalmi múködés önkorrekciójának lehetőségei. A patológiák széles körű megtapasztalása az, amely kikényszeríti a reflexiós érzék feléledését - véli Sik. Amennyiben a reflexió csírái már megjelentek, a következő kérdés az, hogy hogyan lehet a különböző perspektívákból megnyíló tapasztalatokat összegző, a partikuláris szempontok és érdekek szintjén túllépő aktív döntéshozatali folyamathoz vezető párbeszédet kialakítani, mely képes újra lengésbe hozni a modernizáció megakadt ingáját.

A feladat megoldásának első lépéseként a szerző az empirikus kutatások tanulságait összegezve a cselekvői perspektívák tizenhat ideáltípusát vázolja fel a különféle integrációs logikák patológiáinak tapasztalatában való részesedés alapján, majd az ideáltípusok kombinálásával előálló cselekvőpárok osztályozásával jelöli meg az emancipatorikus potenciállal rendelkező interakció-típusokat. Az egymástól gyökeresen eltérő tapasztalati 
mezővel rendelkező cselekvők számára közös világértelmezési keret hiányában nem nyílik lehetőség a kölcsönös tanulás feltételeinek megfelelő interakciók létesítésére. A teljes mértékben azonos cselekvői perspektívával rendelkező típusok interakciója magától értetődő könnyedséggel folyik, nézetegyeztetési kényszer híján azonban nem jellemző rá az emancipatorikus többletteljesítménnyel járó reflexió. A legnagyobb emancipatorikus potenciált azok az interakciók hordozzák, ahol egymástól viszonylag kismértékben eltérő világértelmezési perspektivával rendelkező, egymástól relatíve kis társadalmi távolságra álló cselekvők lépnek interakcióba. A torzításmentes kommunikáción alapuló nézetegyeztetés és demokratikus döntéshozatal ideálját megközelítő diskurzus esélyei akkor a legjobbak, amikor a felek közt elég nagy a szemléletbeli különbözőség ahhoz, hogy szükség legyen a nézőpontok egyeztetésére, de a világértelmezési horizontok nagymértékú átfedése biztosítja az ehhez szükséges alapot, egyszersmind valószínútlenné teszi, hogy a feleknek érvek helyett hatalmi szóra kelljen támaszkodniuk.

A könyv szembetűnő sajátossága, hogy két, tartalmában és fogalmazásmódjában is igen eltérő, nagyjából egyforma hosszú részre oszlik. A mú első felét két elmélet részletes bemutatása teszi ki, második felét pedig négy elmélet gondos elemzése, szintetizálása, majd applikációja - az első féllel azonos terjedelemben. Míg az első esetben a nagyjából száz oldal ehhez éppen megfelelőnek tűnik, a könyv rendkívül sűrüre sikerült második felében némileg kevésnek bizonyul. A bevezető és a záró fejezet lényegre törően, tisztán és érthetően van megírva, ezzel sok segítséget nyújtva az olvasónak az érvelés követésében, Giddens és Lash elméleteinek bemutatása kimondottan élvezetes. A könyv fő tartalmi részét azonban az egyébként világos stílus ellenére is szembetűnően tömör, technikai fogalmazásmód jellemzi. Komoly igényekkel fellépő, elméletek nagy tömegét megmozgató elméleti szintéziseknél ez azonban előny, sőt mi több, olyan követelmény, melyet az érvelés áttekinthetősége iránti jogos igény támaszt. A tartalmilag rendkívül gazdag szöveg azonban ez esetben mégis mintha egy kissé túlzottan össze volna tömörítve; a tudatos elmélettechnikával megformált koncepciót követö, rendszerint hosszabb terjedelmű könyvekre jellemző, Sik által is alkalmazott, sematizáltnak nevezhető írásmód, mikor a szerző az előre felvázolt elméleti keretet követve oszlopról oszlopra, sorról sorra halad a logikai - és az olvasó érdekében rendszerint valódi ábraként is megjelenített - táblázatban, könnyen fedi el az egyes cellák tartalmára vonatkozó, időnként különösen tartalmasnak tűnő kutatási horizontokra utaló rövid megjegyzések mélységét, egyszersmind palástolja az egyes celláknak szentelt figyelem eltéréseit.

Egy elméleti szintézist kínáló mű értékelésénél fontos szempont a kiinduló elméletek köre. A könyv eredményeit számba véve belátható, hogy ezek szelekciója sikeres volt: Sik által történő ütköztetésük figyelemre méltó új észrevételekhez vezet az egyes elméletek erősségeinek és főképp gyengeségeinek vonatkozásában, szintézisük pedig a kiinduló elméletekét meghaladó többleteredményekhez vezet. Különös módon azonban nem leljük nyomát azoknak a szempontoknak, amelyek alapján az adott két-két „klasszikus modern” és „késő modern” szerzőre esett a választás a kínálkozó opciók közül. Bár a könyvet végigolvasva a válogatás szempontjai - amit nyilvánvalóan mélyebb megfontolások motiváltak, mint a szerző puszta ílésbeli preferenciái - többékevésbé rekonstruálhatók, az explicit megfogalmazás rövidsége nincs arányban az elmélet megformáltságának módszerességével és tudatosságával. 
Érdemes továbbá megfigyelni, hogy a kiinduló elméletek köre hogy viszonyul az előző nagyszabású elméleti munkában találhatóhoz. A két mű fókusza közti különbségnek megfelelően A modernitás rétegeiben bevezetésre kerültek a késő modernitás elméletei, azonban a hálózatelméleti megközelítés kiindulópontjai, csakúgy, mint Arendt és Honneth gondolatai, ezúttal kimaradtak a merítésből. Hiányoznak továbbá a fenomenológiai mozgalomhoz kötődő, A modernizáció ingájában oly fontos szerepet játszó filozófusok, bár ez szintén igazolt hiányzásnak tekinthető, mivel a fenomenológiai szemléletmód explicit hatása Giddens és Lash megközelítéseinek áttételén keresztül megőrződött. Az első könyvben szereplő Niklas Luhmann elhagyásával, más hasonló szerzővel való helyettesítésének hiányában a funkcionalista szempontok ezzel szemben érezhető űrt hagyva szorulnak háttérbe, és csak Giddensnek a funkcionalizmus fóáramával szembeni sajátos szembenállásának és egy Habermas által megszürt rendszerfogalomnak a közvetítésén keresztül nyernek merőben negatív természetú képviseletet. Minden bizonnyal ez a változtatás játszik szerepet abban, hogy a rendszerszerü-kibernetikai koordináció viszonyainak megvilágítása megítélésem szerint némileg kevésbé kidolgozott, mint azt az elmélet igényelné. A funkcionalista nézőpont hiánya annál is inkább meglepő, mert a szövegben mind a téma, mind a megfogalmazás terén rendre a rendszerelméleti orientációjú funkcionalizmusra jellemző motívumokba botlunk. Időnként egyenesen a rendszerszerú integráció fő teoretikusa, Talcott Parsons árnya sejlik fel - akinek szelleme már nem csak Habermasnál, de Giddensnél is ott kísértett. Jól tudom, hogy nem illendő egy kritikai társadalomelmélet szerzőjén számon kérni Parsonst - ennek ellenére úgy vélem, hogy mint a társadalmi integráció elméletének megkerülhetetlen alakja, a modernitás szociológiaelméleti tematizálásának klasszikusa, vagy akár a Sik által is követett „szintetikus” társadalomelméleti elméletalkotói paradigma megteremtője, szolgálhatna a vizsgált területen fontos belátásokkal, különösképpen az analitikusan elkülönített társadalmi egységek - és nem csupán alrendszerek - kapcsolódásaira vonatkozóan. ${ }^{5}$ Korántsem véletlen, hogy éppen a modernitás szociokulturális tendenciáit fürkésző, nagy igényekkel fellépő teoretikus munkák szerzői hantolják ki időről időre a már oly sokszor véglegesen eltemetni vélt Parsonst - így tett a Sik elméleti tájékozódásában kulcsszerepet játszó Jürgen Habermas is, aki más munkái mellett már a későkapitalizmus potenciális válságtendenciáinak osztályozásánál is támaszkodott egyes parsonsi szempontokra, demonstrálva, hogy a Parsons-féle analitikus logika a kritikai társadalomelmélet számára is termékeny szempontokkal szolgálhat. ${ }^{6}$

Az utóbbi kritikai észrevételek súlya semmiképpen sem áll arányban a könyv figyelemre méltó eredményeivel. A metaelméleti vizsgálódás tanulságainak gazdagsága, és különösképpen a kialakított összefoglaló általános elmélet - a magyarországi specifikus viszonyok példáján meggyőzően demonstrált - analitikus felbontóképessége mindenképpen elismerést érdemel; az, hogy a szerző, hasonlóan első könyvéhez, ezúttal is megismertet Magyarországon még alig ismert, jelentős kortárs elméletalkotók eredményeivel, már csak ráadás. A könyv olvasása közben jól látható: nem csak az empirikus társadalomkutatásnak, de az elméletalkotásnak is megvan a maga módszertana, és Sik Domonkos ezen a színtéren egyedülállóan otthonosan mozog. A könyv A modernizáció ingája figyelemreméltó elméleti teljesítménye és a Demokratikus kultúra és modernizáció egyértelmú empirikus elkötelezettsége fényében vizsgálva is vállalkozása méltó folytatásának tekint-

5 Lásd Alexander 1996, Robertson-Turner 1991. Ezen a ponton talán érdemes felhívni a figyelmet arra, hogy a közkeletű elképzeléssel szemben Parsons nem tekintette a korabeli Egyesült Államok által járt utat az egyetlennek, amelyen a kibontakozó modernitás járhat, lásd Parsons 1977.

6 Habermas 1973 (hosszabb részlet a műből, magyar nyelven: Habermas 1994); lásd még Habermas 2011 
hető. A modernitás rétegeiben kidolgozott fogalmi séma kellően komplex a társadalmi integráció elemeinek analitikus áttekintéséhez, egyszersmind kellően kimunkáltnak tûnik ahhoz, hogy empirikus kutatások elméleti keretéül szolgáljon. A könyv két irányba közvetlen kiindulópontot is szolgáltat: egyet az elmélet továbbalkotása felé (melyet a szerző kilátásba is helyez a mú eredményeinek A modernizáció ingája hálózatelméleti keretébe illesztésének megelőlegezésével), a másikat pedig a rendszerváltás utáni Magyarország integrációs viszonyainak a modell alapján történő részletezőbb - jelen kötetben nyilvánvaló terjedelmi okokból véghezvihetetlen - bemutatása felé. Bármelyik mellett is döntsön a szerző - vagy döntsön a szintézis mellett, mint szokása -, bizakodással várhatjuk a folytatást.

\section{HIVATKOZÁSOK}

Alexander, J. C. (1996) Szociológiaelmélet a II. világháború után. Budapest: Balassi.

Habermas, J. (1973) Legitimationsprobleme im Spätkapitalismus. Frankfurt am Main: Suhrkamp.

Habermas, J. (1994) Válságtendenciák a kései kapitalizmusban. In Válogatott tanulmányok. Budapest: Atlantisz

Habermas, J. (2011) A kommunikativ cselekvés elmélete. Budapest: Gondolat.

Sik D. (2012) A modernizáció ingája. Egy genetikus kritikai elmélet vázlata. Budapest: ELTE Eötvös.

Sik D. (2013) Lash modernitáselmélete. Jel-Kép 3-4. Hozzáférhetó: http://communicatio.hu/jelkep/2013/3_4/sik_domonkos.htm [letöltve: 2016-09-16] http://dx.doi.org/10.20520/jel-kep.2013.3-4.2

Sik D. (2014a) Demokratikus kultúra és modernizáció. Állampolgári szocializáció 20 évvel a rendszerváltás után. Budapest: L'Harmattan.

Sik D. (2014b) A klasszikus és késő modernitás egyesített elmélete. socio.hu 4, 150-181. Hozzáférhető: http://socio.hu/uploads/ files/2014_4/7sik_tanulmany.pdf [letöltve: 2016-09-16] http://dx.doi.org/10.18030/socio.hu.2015.1.246.

Sik D. (2015) Klasszikus és késő modernitás a rendszerváltás utáni Magyarországon. socio.hu 1, 246-274. Hozzáférhető: http://socio. hu/uploads/files/2015_1/sik.pdf http://dx.doi.org/10.18030/socio.hu.2015.1.246.

Parsons, T. (1977) The Evolution of Societies. Englewood Cliffs: Prentice-Hall.

Robertson, R. - Turner, B. S. (1991) Talcott Parsons: Theorist of Modernity. London: Sage. 